\title{
ANALYSIS OF THE LAYOUT OF THE FINISHED GOODS WAREHOUSE USING THE SHARED STORAGE METHOD TO INCREASE STORAGE EFFECTIVENESS IN PT. NCS LOGISTIC LINK
}

\author{
Putri Shima1, Akhmad Syakhroni, ST, M.Eng² \\ ${ }^{1}$ Univesitas Islam Sultan Agung (UNISSULA) \\ Jl. Raya Kaligawe KM.4 Semarang email : putrishima@std.unissula.ac.id \\ 2 Univesitas Islam Sultan Agung (UNISSULA) \\ Univesitas Islam Sultan Agung (UNISSULA), email : syakhroni@unissula.ac.id
}

\begin{abstract}
PT NCS LOGISTIC LINK is a Transportation Management Service company or commonly called Freight Forwarding. PT. NCS is also engaged in the rental of Warehouses. In the Warehouse at PT NCS LOGISTIC LINK, there is a problem with the layout of the storage of goods in the Warehouse which is still not optimal because the cost of Material Handling in the company is still high and also PT NCS LOGISTIC LINK, a company that manages warehouse rental for companies manufacture. The problems faced by PT NCS LOGISTIC LINK today are the problems that are often faced is the handling of incoming and outgoing goods in the company's warehouse, the company still does not have a defined system, so that the placement of goods in the warehouse is not neatly arranged so that the warehouse seems narrow. Likewise, the warehouse line or line layout is not clear, the placement of finished goods for both export and local products is placed in one location with the material (Completely Knock Down / CKD) in one warehouse location, there is no barrier between the goods belonging to one customer and another. other things, goods are placed to close the road area or forklift lanes and warehouse doors, and goods that have entered earlier are closed with new incoming goods, thus hampering the process of handling goods. With limited storage space, companies are required to use space effectively and efficiently so that storage activities are not hampered and can find the best layout that is more effective and efficient and does not hamper the delivery process. The method used in warehousing management is a shared storage approach in which the products that have the most shipping frequency and the ones that frequently go in and out are brought close to the entrance to minimize the distance of material handling movement. The results of the shared storage approach can minimize the material handling distance of the proposed layout is $1386 \mathrm{~m}$, while the previous condition, the initial layout distance was $1900 \mathrm{~m}$. Has a total range of 514 meters of total mileage. This means that the layout of the proposal could shorten the mileage through which warehouse workers take goods.
\end{abstract}

Keywords: Metode Shared Storage, Material Handling

This is an open access article under the CC BY license.

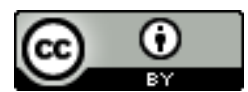

\section{INTRODUCTION}

PT NCS LOGISTIC LINK is a Transportation Management Service company or commonly called Freight Forwarding. Established in Jakarta since 1996, is one of the international freight forwarders domiciled in Jakarta, which is supported by experienced personnel in their respective fields. As an International Freight Forwarding, PT NCS LOGISTIC LINK has received a license and qualification from NVCC, Ocean Freight Forwarder (USFMC), International Air Transportation (IATA), International Federation of Freight Forwarders Associations (FIATA) and Ministry of Communication (IMOC). Freight forwarder is a business entity that 
aims to provide services / management of all activities required for the delivery, transportation and receipt of goods by using multimodal transport by land, sea and air (Suyono, 2007: 251).

Besides that, PT. NCS is also engaged in warehouse rental. The Warehouse at PT NCS LOGISTIC LINK has a problem with the layout of the storage of goods in the Warehouse which is still not optimal because the cost of Material Handling in the company is still high and also PT NCS LOGISTIC LINK, a company that manages warehouse rental for manufacturing companies. The problem that is often faced is that in handling incoming and outgoing goods in the company's warehouse, the company still does not have a defined system, so that the placement of goods in the warehouse is not neatly arranged so that the warehouse seems narrow. Likewise, the warehouse line or line layout is not clear, the placement of finished goods for both export and local products is placed in one location with the material (Completely Knock Down / CKD) in one warehouse location, there is no barrier between the goods belonging to one customer and another. other things, goods are placed to close the road area or forklift lanes and warehouse doors, and goods that have entered earlier are closed with new incoming goods, thus hampering the process of handling goods. Its position, not based on a good design, makes it difficult for warehouse officers and forklift operators when placing, storing and retrieving goods, so that the process of moving goods to a predetermined area takes a long time. Being the cause of material handling or less effective and efficient.

\section{LITERATURE REVIEW}

According to (Heizer \& Render, 2009) warehouse layout is a design that tries to minimize total costs by finding the best guide between space area and material handling.

According to research conducted by Jauhari Arifin, Arifin Pamungkas, the Shared Storage method is used to overcome dedicated storage and randomized storage by recognizing and utilizing differences in storage time for certain pallets that settle in the warehouse. To apply this method, we must know in advance when the product will enter and when it will come out, so that the product location can be adjusted accordingly. Arrangement of storage areas based on the condition of the warehouse floor area, then sorted the closest area to the area farthest from the I / $\mathrm{O}$ exit door so that the placement of goods to be sent immediately is placed in the area closest to.

The next research has been conducted by Firman Ardiansyah Ekoanindiyo, Yaumal Agit Wedana regarding Warehouse Layout Planning Using the Shared Storage Method in the Semarang City Plastic Factory. The results of the Shared Storage method will be maximized if used in a plastic factory warehouse that has 2 types of products. The total area for space requirements for storage pallets for raw materials and finished products is $64 \mathrm{~m}^{2}$.

The next research is what has been done by Qomariatus Sholihah regarding the Use of Shared Storage Methods in Layout Planning in PT. X obtained the results from the research, namely the storage area used is wooden pallets, to save the area, 6 levels are collected on each pallet with the arrangement of $2 \times 2$, so each pallet consists of food and beverage products, done to facilitate the arrangement of products to the storage area and also to save space utilization. The aisle is used as a material handling aisle or pathway, personnel movement movement. The material handling used is a handpallet. So the required aisle is based on the need for the line according to the dimensions of the handpallet.

The next research is that which has been conducted by Indra Sukoco regarding Warehouse Layout Design at PT Panatrade using the Shared Storage method. The results obtained are that the proposed layout has a smaller total mileage than the initial layout with improved storage media arrangement. The total mileage of the initial layout is 124,295 meters. The total mileage of the proposed layout is 24,225 meters. There is a difference in the total value of 100.070 meters from the initial total distance traveled. This means that the proposed layout can shorten the distance traveled by warehouse employees in retrieving goods.

The next research is that which has been conducted by Indra Sukoco regarding Warehouse Layout Design at PT Panatrade using the Shared Storage method. The results obtained are that the proposed layout has a smaller total mileage than the initial layout with improved storage media arrangement. The total mileage of the initial layout is 124,295 meters. The total mileage of the proposed layout is 24,225 meters. There is a difference in the total value of 100,070 meters from the initial total distance traveled. This means that the proposed layout can shorten the distance traveled by warehouse employees in retrieving goods.

Other research that has been conducted by Moch. Syayidi Sofyan, Atikha Sidhi Cahyana regarding Relayout of Finished Goods Warehouses to Maximize Finished Product Capacity Using the Activity Relationship Chart and Shared Storage Methods obtained from the research, namely the layout of the proposal has a proposal for moving some existing facilities in the transit warehouse so that it can optimize the capacity of the transit warehouse with an initial capacity of 44 storage areas and the proposed layout value having a capacity of 61 storage areas, hereby the value of the proposed layout capacity is greater than the initial layout. Using the activity relation chart and shared storage methods is very good when applied in production companies, especially in transit warehouse areas because it can mathematically optimize the capacity of the 
transit area and minimize the mileage of the handlifts. And need special attention in placing finished goods in transit warehouses to increase work effectiveness.

\section{RESEARCH METHOD}

The research method is a way of thinking that starts from determining a problem, collecting data both through guidebooks and field studies, conducting research based on existing data to drawing conclusions from the problem under study. Research must have clear goals and directions. With clear and well-planned goals, research activities will become clear. Therefore it is necessary to have a systematics that will be carried out with appropriate methods and procedures leading to predetermined targets or targets.

In the research method, a method or procedure is planned along with the stages that are clear and systematically arranged in the research process. Each stage is a part that determines the next stage so that it must be passed carefully.

1. Research Place

The research was conducted at PT. NCS LOGISTIC LINK Cikrang - Bekasi.

2. The object of research

The research object is the facilities of PT. NCS LOGISTIC LINK Cikrang - Bekasi

3. Problem Identification

The problem identification stage is a way for researchers to predict, estimate and describe what is the problem in the company. The identification of problems in this study consists of:

a. Field observation

This stage aims to determine the real conditions that exist in the company, by obtaining this description, it is expected to find out what criteria are in accordance with the company standards.

b. Literature review

Literature study is carried out by looking for references from several sources in the form of books, journals, scientific articles, etc. that can support research and can then be used to solve problems according to the topic.

c. Formulation of the problem

From the background description of the problem above, the problems experienced by the PT NCS LOGISTIC LINK warehouse can be formulated, namely how to design an effective warehouse layout at PT NCS LOGISTIC LINK using the Shared Storage method.

4. Data Collection

This stage is carried out to collect the data needed for research. The data needed by researchers include:

a. Primary data

Primary data is data obtained from original sources (without going through intermediary media). Primary data can be in the form of individual or group opinion of the subject (person), the results of observations on an object (physical), events or activities resulting from testing. This data is obtained from interview methods with competent parties regarding the production line.

b. Secondary Data

Secondary data is data obtained by researchers indirectly. Secondary data is usually in the form of documents, files, archives or company records. This data was obtained through company documentation and literature related to research during a certain period. Secondary data in this study are types of raw materials and complaints, delivery time, service.

5. Data Processing

The data that has been collected is then processed by the method used is Shared Storage to determine the solution to the problem.

6. Analysis and Interpretation of Results

At this stage, an analysis of the results of the data processing that has been done before is given. The analysis is carried out starting from the beginning, from data processing to the results of the Shared Storage method.

7. Conclusions and Suggestions

The final stage of this research is drawing conclusions on the overall results obtained from the research steps carried out. This conclusion is the answer to the existing problems. In addition, suggestions will also be given as positive input related to the research results.

Vol.01, No.01, Januari, $2021: 26$ - 35 


\section{RESULT AND ANALYSIST}

4.1 Data Accumulation

\subsubsection{Data Type Of Product}

1. Petrol Export

Annotation :

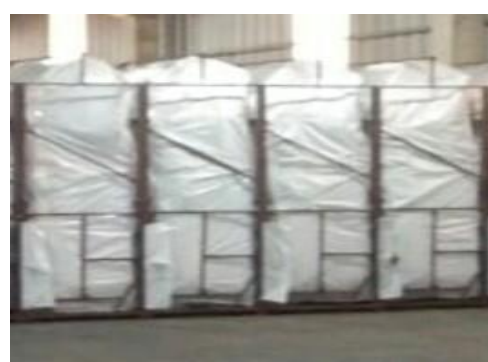

Figure 1. Petrol Export

Dimension

Stacked

: P X L X T $=(135 \mathrm{~cm} \times 93 \mathrm{~cm} \times 253 \mathrm{~cm})$ : cannot be stacked

\section{Parts}

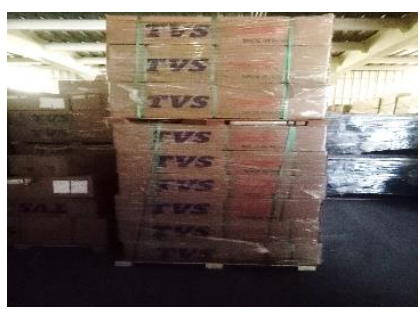

Figure 2. Parts

Annotation :

Dimension

: P X L X T = ( $120 \mathrm{~cm} \mathrm{x} 93 \mathrm{~cm} \mathrm{x} 100 \mathrm{~cm})$

Stacked

: Double Stack )

3. Frame Assy

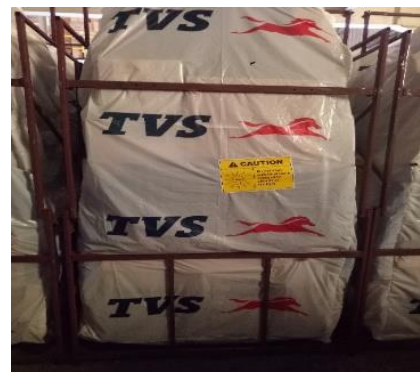

Figure 3. Frame Assy

Annotation :

Dimension

Stacked

$: \mathrm{P} \times \mathrm{L} \times \mathrm{T}=(135 \mathrm{~cm} \times 93 \mathrm{~cm} \times 253 \mathrm{~cm})$

: ( cannot be stacked)

\subsubsection{Data Warehouse}

The data needed is the data on receipt of goods in the warehouse of PT. NCS LOGISTIC LINK, at the TVS Motor warehouse, this data was generated from the results of a month of research at PT. NCS LOGISTIC LINK.

Table 1. of the table Data Customer PT. TVS Motor Company Indonesia

\begin{tabular}{|c|c|c|c|}
\hline No & Description & Receiving & Jumlah (pallet) \\
\hline 1. & (Model Petrol Export) & 360 & 360 \\
\hline 2. & Frame Assy & 220 & 220 \\
\hline 3. & Parts & 100 & 100 \\
\hline \multicolumn{2}{r|}{ Totally } & 680 & 680 \\
\hline
\end{tabular}


Information:

- $\quad$ In that period of month, 680 pallets / structures were received for imported goods, consisting of three types of goods, namely Petrol Export Model: 360 Pallet, Frame Assy: 220 pallet and Parts: 100 Pallet.

From the data table, it can be seen that the stock at the end of the month was 680 pallets / structure

\subsubsection{Inbound-Outbound Warehouse}

PT. NCS LOGISTIC LINK has several warehouses, and these warehouses function as InboundOutbound warehouses, for relations or tenants. As the warehouse operated for TVS Motor Indonesia, has an area / dimensions: P X L X M: (54 M X 24 M) = 1.296 M2.

\subsection{Data Processing}

After the necessary data is obtained, and the collection is carried out, the next step is data processing based on the theory used, namely the shared storage method.

The Shared Stoaged method is to arrange a storage arena based on circumstances, with a close to far order from the entrance with the placement of goods and subsequent placement.

\subsubsection{Space TVS (Gudang TVS)}

As it is known that PT. NCS LOGISTIC LINK as the provider or warehouse owner rents out space (warehouse) to PT.TVS MOTOR COMPANY INDONESIA based on the rental agreement or Warehouse Agreement. In relation to the Inbound-outbound warehouse / warehouse, TVS Motor Company Indonesia has agreed to rent a warehouse or warehouse space with an area of $1000 \mathrm{M} 2$, and if in practice there is additional space then the additional space will automatically be added as additional space or additional warehouse space that must be billed. rent to the tenants.

Table 2. Of The Table Space TVS

\begin{tabular}{|c|c|c|c|c|c|}
\hline No. & Area & $\begin{array}{c}\text { Approved Space By } \\
\text { TVS (SQM) }\end{array}$ & $\begin{array}{c}\text { Actual Space } \\
\text { Occupied (SQM) }\end{array}$ & $\begin{array}{c}\text { Excess ( } \\
\text { Storage })\end{array}$ & Remarks \\
\hline 1 & $\begin{array}{c}\text { Warehouse } \\
\text { TVS }\end{array}$ & $1.000 \mathrm{M} 2$ & $1.240 \mathrm{M} 2$ & $240 \mathrm{M}$ & $\begin{array}{c}\text { Total Space }: 1.296 \\
\text { M2(SQM) }\end{array}$ \\
\hline & & $1.000 \mathrm{M} 2$ & $1.240 \mathrm{M} 2$ & & \\
\hline
\end{tabular}

Information :

- From the table, it is known that in accordance with the rental agreement (Warehouse Agreement) the space that has been approved as warehouse rental space for TVS Motor Indonesia to store goods or products for three-wheeled motorbikes is $1000 \mathrm{M} 2$, out of a total warehouse space of 1,296 M2

- The actual space usage is 1,240 M2, an additional $240 \mathrm{M} 2$ of space has been added

- From the total warehouse space area of 1,296, with 1,240 used space it can accommodate all goods or products of a tricycle.

\subsubsection{Determination of the Storage Area}

The storage area used is Warehouse 2, with a warehouse floor area of 1,296 M2. In the case of goods or products that will be placed because they are already in a packaging or packing in a pallet, crate or structure, then they do not use wooden pallets. In planning the layout of goods or products to facilitate the process of receiving, storing and releasing goods or products, first determine the area of the placement area by dividing it into several vacancies or spaces per each column.

To determine the storage area of the formula I took based on journals, proceedings, and the final project regarding the warehouse layout using the shared storage method with the calculation of rectilinier distance. As one of the references in the final project entitled "Designing a Warehouse Layout at PT Panatrade using the shared storage method" by Indra Sukoco, Universitas Mercu Buana 2017.

The division or determination of the storage area using mathematical calculations is as follows:

The area for storing TVS products with warehouse floor dimensions is $54 \mathrm{~m} \times 24 \mathrm{~m}=1,296 \mathrm{~m} 2$

Storage Area $=(2)$ product length $\mathrm{x}(2)$ product width

Storage Area $=(2) 1.35 \mathrm{mx}(2) 0.93 \mathrm{~m}=1.26 \mathrm{~m}^{2}$

The amount of storage area required is:

Vol.01, No.01, Januari, $2021: 26$ - 35 


$$
\begin{aligned}
\text { Storage Area needs } & =\frac{\text { Product total }}{\text { A lot of products in one area }} \\
& =\frac{680}{40}=17
\end{aligned}
$$

Space requirements to accommodate the number of pallets $=750$ pallets $(750 \times 1.26=945 \mathrm{~m} 2)$. So from 750 products, it requires 18 areas of space with an extensive finished Product Warehouse with dimensions of $54 \mathrm{~m} \times 24 \mathrm{~m}$, meeting the space requirements of 1,296 m2.

\subsubsection{Determinatin of Space Allowance}

Aisle space or allowance is a space that can serve as a space for a pathway for material handling activities. Allowance is used as an aisle or material handling pathway, material handling used is a forklift as a means of transporting goods, and warehouse officers for activities in the warehouse. So allowance is needed based on what is needed for measuring the dimensions of the forklift. Calculated from the longest dimension of the forklift when carrying the product required in determining the area of the aisle, either one way or two directions when it passes. Determination of the area of the alley or allowance, can be seen in Figure 4.5, with length (p) $2.80 \mathrm{~m}$, and width (1) $1.30 \mathrm{~m}$.

$$
\text { Diagonal }=\sqrt{\mathrm{p}^{2}+1^{2}}=\sqrt{2,80^{2}+1,30^{2}}=3,6 \mathrm{~m}
$$

By knowing the allowance required, it can be determined that the width of the alley is $3.6 \mathrm{~m}$.

\subsubsection{Laying the initial Storage Area}

At the initial layout storage at the warehouse of PT. NCS LOGISTIC LINK warehouse conditions there are still very unorganized, storage is placed in a variety of products. So that the data that I take is based on the warehouse conditions there are as follows;

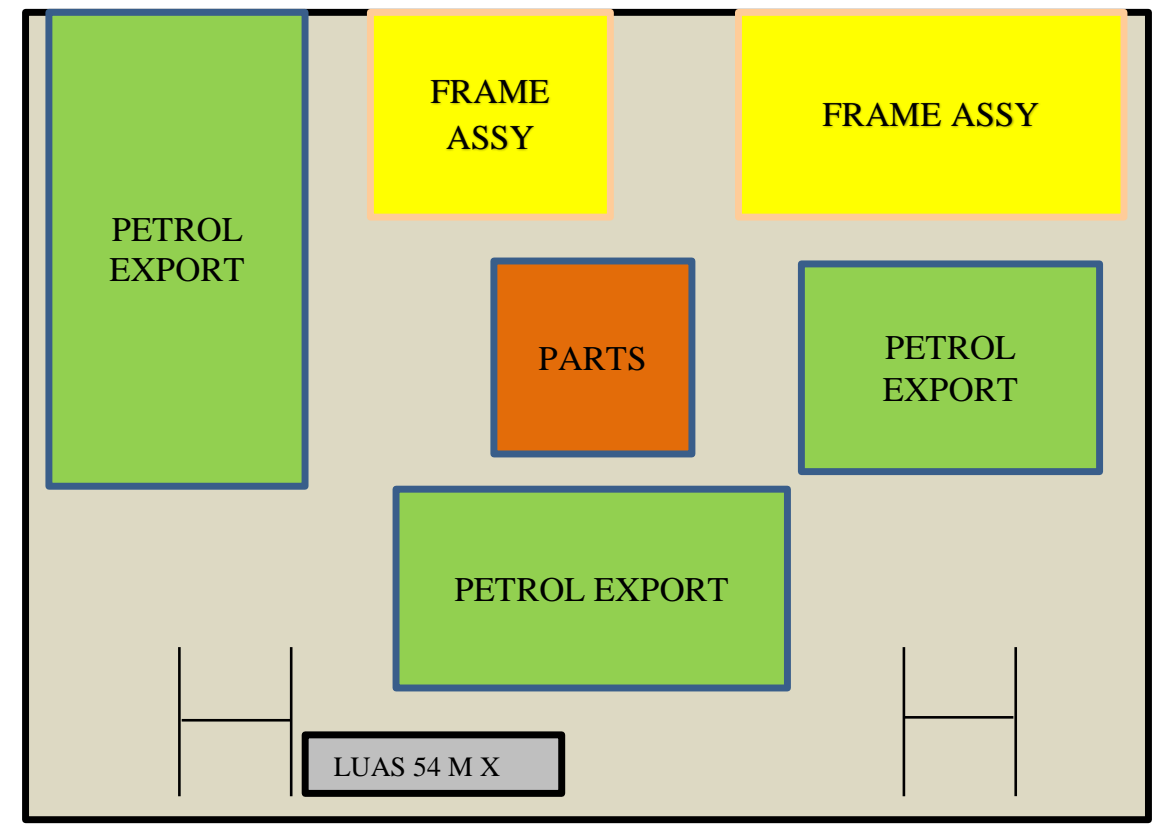

Figure 1. Intial Layout 


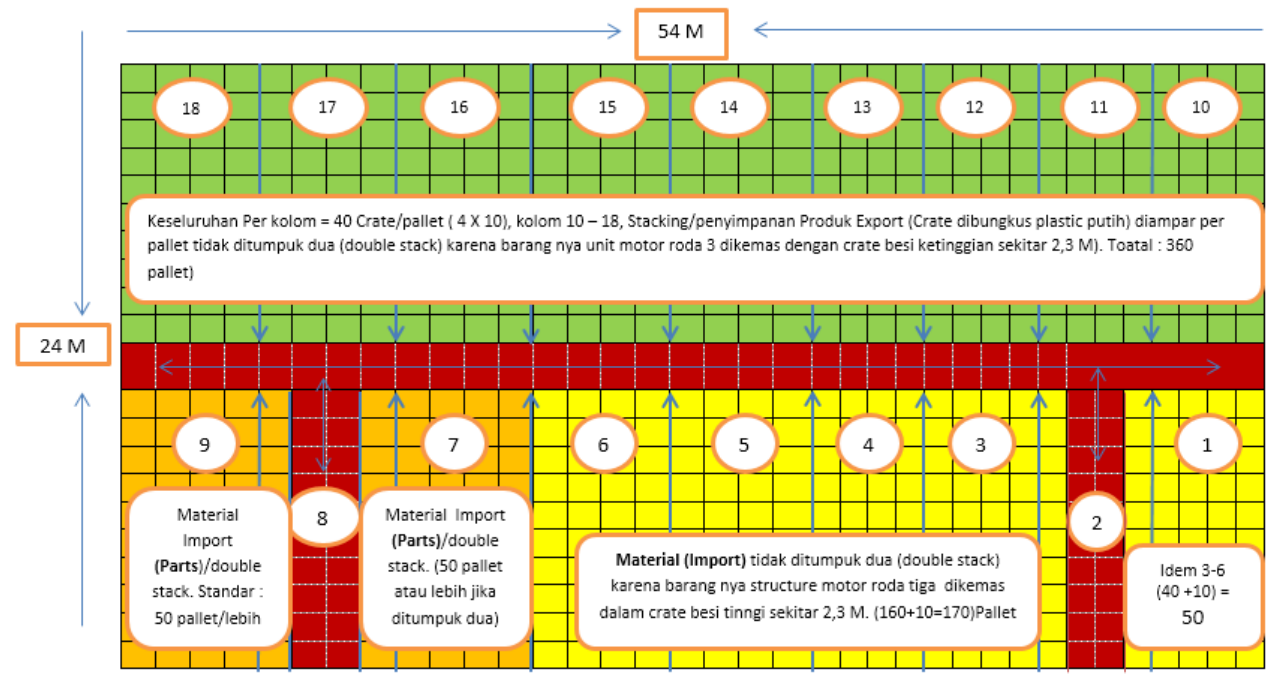

Figure 2. Proposition Layout

\subsubsection{Distance from Storage Area to Door}

Placement of the area based on the type of product that has the highest average frequency or the product that often exits is closer to the entrance and exit. The distance between material handling is starting from the door ( $\mathrm{I} / \mathrm{O}$ ) to the storage area, the calculation of the distance is done using the Rectilinear Distance method. The distance is measured along the path using a perpendicular (orthogonal) line to the point of each storage area with the formula:

Dimana :

$$
d_{i j}=|x i-x j|+|y i-y j|
$$

$\mathrm{dij}=$ distance between facility centers $\mathrm{i}$ and $\mathrm{j}$ (meters).

$x i=$ The $x$ coordinate at the center of the facility $i$

$x j=$ The $x$ coordinate at the center of the facility $j$

$\mathrm{yi}=\mathrm{y}$ coordinate at facility center $\mathrm{i}$

$\mathrm{yj}=\mathrm{y}$ coordinate at facility center $\mathrm{j}$

A Sample Calculation :

$$
\begin{aligned}
& A 1=d_{i j}=|x i-x j|+|y i-y j| \\
& =|1-6|+|10,5-1| \\
& =|5|+|9,5| \\
& =14,5 \\
& A 2=d_{i j}=|x i-x j|+|y i-y j| \\
& =|1-12|+|10,5-1| \\
& =|11|+|9,5| \\
& =20,5
\end{aligned}
$$

Table 3 . Of The Table Code and Mileage between the door to the storage area

\begin{tabular}{|c|c|c|}
\hline No & Storage Area & Distance (m) \\
\hline 1 & A1 & 14,5 \\
\hline 2 & A2 & 20,5 \\
\hline 3 & A3 & 26,5 \\
\hline 4 & A4 & 32,5 \\
\hline 5 & A5 & 38,5 \\
\hline 6 & A6 & 44,5 \\
\hline 7 & A7 & 50,5 \\
\hline 8 & A8 & 56,5 \\
\hline
\end{tabular}




\begin{tabular}{|c|c|c|}
\hline No & Storage Area & Distance (m) \\
\hline 9 & A9 & 62,5 \\
\hline 10 & B1 & 14,5 \\
\hline 11 & B2 & 20,5 \\
\hline 12 & B3 & 26,5 \\
\hline 13 & B4 & 32,5 \\
\hline 14 & B5 & 38,5 \\
\hline 15 & B6 & 44,5 \\
\hline 16 & B7 & 50,5 \\
\hline 17 & B8 & 56,5 \\
\hline 18 & B9 & 62,5 \\
\hline
\end{tabular}

Average Material Handling Mileage per Month Using the Proposed Warehouse Layout The calculation of material handling mileage is carried out in the period considered to have average demand and average delivery (period) obtained from the previous data

Table 4 . Of The Table Demand data period 2

\begin{tabular}{|c|c|c|c|}
\hline No & Description & Receiving & Jumlah (pallet) \\
\hline 1. & (Model Petrol Export) & 360 & 360 \\
\hline 2. & Frame Assy & 220 & 220 \\
\hline 3. & Parts & 100 & 100 \\
\hline \multicolumn{2}{r|}{ Total } & 680 & 680 \\
\hline
\end{tabular}

In the application of compiling based on the shared storage method, a warehouse card is designed to make it easier to organize products for a certain 2 nd period of time based on name and first sent Procedure for filling into storage area:

1. Products arriving first and which are shipped first are placed in the empty storage area closest to the door (with levels from closest to farthest).

2. To facilitate product identification in the warehouse, there should be no 2 or more types of products in 1 storage area.

3. The standard for stacking products is a maximum of 2 levels, where when placing the product it is placed in an empty slot in the closest area then it is stacked then another slot is filled with the same conditions.

\section{Results and Discussion}

Shared storage is a method of arranging the layout of warehouse space using the FIFO (First In First Out) principle where the fastest goods sent are placed in the storage area closest to the exit - entry (I / O). This method will be better used in types of factories that have the same product dimensions or are not much different, because each storage area can be occupied by different types of products based on the production time and date of delivery of the product.

PT.NCS Logistik Link is one of the companies that has warehouse rentals with almost all the same dimensions and has problems that are experienced by finished goods warehouses at this time, namely the arrangement of products in one area that is irregular, and the placement of products per area is still not precise, where products that frequently go in and out are placed in a part that is far from the doorway and the handpallet allowance is widened and narrowed so that there is inefficiency in the passage of space to get out - the entry of material handling and it is also difficult to take hospitalization every month because of the irregularity of the same goods Also, from the problems that exist in PT.NCS Logistik Link, there is a solution that can be solved by using one method, namely the shared storage method. 
Table 5 . Of The Table Comparative Analysis of Material Handing Distance between Initial Warehouse Layout and Proposed Warehouse Layout Initial Layout Material Handling Mileage

\begin{tabular}{|c|c|c|c|c|}
\hline No & Storage Area & Product & $\begin{array}{c}\text { Receiving Distance } \\
(\mathbf{m})\end{array}$ & $\begin{array}{c}\text { Total Mileage } \\
(\mathbf{m})\end{array}$ \\
\hline 1. & A1 & Frame Assy & 57 & 114 \\
\hline 2. & A2 & Frame Assy & 57 & 38 \\
\hline 3. & A3 & Frame Assy & 57 & 114 \\
\hline 4. & A4 & Frame Assy & 57 & 114 \\
\hline 5. & A5 & Frame Assy & 57 & 114 \\
\hline 6. & A6 & Frame Assy & 57 & 114 \\
\hline 7. & A7 & Parts & 57 & 38 \\
\hline 8. & A8 & Parts & 19 & 114 \\
\hline 9. & A9 & Petrol Export & 57 & 114 \\
\hline 10. & B1 & Petrol Export & 57 & 114 \\
\hline 11. & B2 & Petrol Export & 57 & 114 \\
\hline 12. & B3 & Petrol Export & 57 & 114 \\
\hline 13. & B4 & Petrol Export & 57 & 114 \\
\hline 14. & B5 & Petrol Export & 57 & 114 \\
\hline 15. & B6 & Petrol Export & 57 & 114 \\
\hline 16. & B7 & Petrol Export & 57 & 114 \\
\hline 17. & B8 & Petrol Export & 57 & $\mathbf{1 9 0 0}$ \\
\hline 18. & B9 & 950 & \\
\hline & & & \\
\hline
\end{tabular}

Table 5 . Of The Table Mileage Material Handling Proposed Layout

\begin{tabular}{|c|c|c|c|c|}
\hline No & Area Penyimpanan & Produk & $\begin{array}{c}\text { Jarak Tempuh Saat } \\
\text { Penerimaan (m) }\end{array}$ & $\begin{array}{c}\text { Jarak Tempuh } \\
\text { Total (m) }\end{array}$ \\
\hline 1. & A1 & Frame Assy & 14,5 & 29 \\
\hline 2. & A2 & Frame Assy & 20,5 & 41 \\
\hline 3. & A3 & Frame Assy & 26,5 & 53 \\
\hline 4. & A4 & Frame Assy & 32,5 & 65 \\
\hline 5. & A5 & Frame Assy & 38,5 & 77 \\
\hline 6. & A6 & Parts & 44,5 & 89 \\
\hline 7. & A7 & Parts & 50,5 & 101 \\
\hline 8. & A8 & Parts & 66,5 & 113 \\
\hline 9. & A9 & Petrol Export & 14,5 & 29 \\
\hline 10. & B1 & Petrol Export & 20,5 & 41 \\
\hline 11. & B2 & Petrol Export & 26,5 & 63 \\
\hline 12. & B3 & Petrol Export & 32,5 & 77 \\
\hline 13. & B4 & Petrol Export & 38,5 & 89 \\
\hline 14. & B5 & Petrol Export & 44,5 & 101 \\
\hline 15. & B6 & Petrol Export & 50,5 & 113 \\
\hline 16. & B7 & Petrol Export & 56,5 & 125 \\
\hline 17. & B8 & Petrol Export & 62,5 & $\mathbf{1 3 8 6}$ \\
\hline 18. & B9 & $\mathbf{6 9 3}$ & \\
\hline & & & & \\
\hline
\end{tabular}

After collecting data and processing data using the shared storage method in the finished product warehouse at PT.NCS Logistik Link, it can be concluded that the proposed layout has a smaller total mileage than the initial layout with improved storage arrangements and layouts. The total mileage of the initial layout is 1900 meters. The total mileage of the proposed layout is 1386 meters. There is a difference in the total value of the layout mileage of 514 meters from the initial total mileage.

Vol.01, No.01, Januari, $2021: 26$ - 35 


\section{CONCLUSION}

\subsection{Conclusion}

1. The total mileage on the proposed layout is smaller than in the initial layout after improving the storage method. The total mileage of the initial layout is 1900 meters. The total mileage of the proposed layout is 1386 meters. Has a difference in the value of the total distance traveled by 514 meters from the total initial mileage. This means that the proposed layout can shorten the distance traveled by warehouse employees in retrieving goods.

2. The total required storage area is 18 areas, with the required area is $356 \mathrm{~m} 2$. The width of the aisle required for the forklift is $3.6 \mathrm{~m}$, an empty warehouse area with an area of $56 \mathrm{~m} 2$.

3. Arrange the ones that become proposals, make it easier for the warehouse in the process of picking up goods because the warehouse has been allocated according to the placement of goods and the aisles for access are neatly arranged.

5.2 Saran

1. The shared storage approach is good if the application of the warehouse company is to minimize the mileage of the forklift and to save on material handling operational costs.

2. There is a sign on the placement in the warehouse, with the warehouse supervisor who is not difficult to carry out the process of placing the goods in an empty area by sending them, not making it difficult for the operator to send them.

3. Special attention is required for the placement of the forklift in the warehouse and for increasing work effectiveness.

\section{REFERENCES}

[1] Arifin, J., \& Pamungkas, T. "Warehouse Layout Improvement Using the Shared Storage Method at Perum Bulog, Karawang Subdivre.," vol. 3, no. 1, pp. 7-14, 2019.

[2] M. Ilham, "Export Warehouse Layout Design Pt. New Hadi With The Shared Storage Method," 2009.

[3] F. A. Ekoanindiyo et al., "Warehouse Layout Planning Using the Shared Storage Method in a Plastic Factory in the City of Semarang," pp. 46-57, 2012.

[3] P. Flora and R. Tani, "The design of the warehouse layout for door leaf products using the Shared Storage method at PT. Putra Flora Rimba Tani," 2016.

[4] P. Satria, A. Santoso, L. Herlina, and E. Febianti, "Proposed Layout of Finished Product Warehouse Using Shared Storage Method and Simulation Approach at PT. Lotte Chemical Titan Nusantara," 2001.

[5] Q. Sholihah, "Use of the Shared Storage Method in Planning Layout in the Warehouse PT. X," vol. 2017, pp. 4-6, 2017.

[6] I. Sukoco, "Warehouse Layout Design At PT. Panatrade using the Shared Storage method," pp. 1-75, 2017.

[7] Sugiyono, A. (2020). Clustering Approach on Layout Redesign to Optimize Container Handling Process. Jurnal Kejuruteraan, 32(2), 349-356.

[8] M. Zaenuri, "Evaluation Of Warehouse Layout Design Using Shared Storage Method In Pt. International Premium Pratama Surabaya," vol. XV, no. 2, pp. 21-36, 2015.

[9] M. S. Sofyan and A. S. Cahyana, "Finished Goods Warehouse Relayout To Maximize Finished Product Capacity Using Activity Relation Chart And Shared Storage Methods," Spektrum Ind., vol. 15, pp. 121$255,2017$. 